FACTA UNIVERSITATIS

Series: Philosophy, Sociology, Psychology and History Vol. 18, No 1, 2019, pp. 1 - 14

https://doi.org/10.22190/FUPSPH1901001T

Original Scientific Paper

\title{
TOLERANCE, MULTICULTURALISM AND INTERCULTURALISM IN THE BALKANS *
}

\author{
UDC 316.72(497)
}

\section{Dragan Todorović}

University of Niš, Faculty of Philosophy, Department of Sociology, Serbia

\begin{abstract}
A multicultural society should possess the characteristics of a society in which different ethnic groups live together but with no interaction. The minority groups living therein are passively tolerated without being accepted by the majority group. An intercultural society should be defined as a society in which different groups live together and exchange their life experiences with mutual respect for their different styles of life and values. That is why a correct starting definition of interculturalism would be that interculturalism is a critique and an alternative to multiculturalism. It is possible for the members of different cultures to live close to each other and that is the most crucial characteristic of multicultural societies. An intercultural society represents a society in which we live and create not close to each other but with each other and for each other.

Accordingly, the contemporary Balkan society is facing the process of its transition from the multicultural into the intercultural one, that is, the process of spreading and adopting the idea and practice of interculturalism in a multicultural community. More precisely, this implies the development of the concept of a cultural and educational policy that would foster appreciation of cultural diversity and lead to the creation of a society in which different cultures interpenetrate.

At the end of the paper the measures of the public cultural politics of the Balkan countries aiming at improvement and advancement of the existing intercultural dialogue are summed up.
\end{abstract}

Key words: Balkans, Dialogue, Tolerance, Multiculturalism, Interculturalism, Measures of Public Cultural Policy.

Received May 13, 2010 / Accepted May 20, 2019

Corresponding author: Dragan Todorović

University of Niš, Faculty of Philosophy, Ćirila i Metodija 2, 18000 Niš, Serbia E-mail: dragan.todorovic@filfak.ni.ac.rs

* A plenary talk at the international scientific conference "Migrations and Identity: Culture, Economy, State", held in Zagreb from December 6 to 8, 2018, and organized by the Institute for Migration and Ethnic Studies from Zagreb (Croatia). 


\section{INTRODUCTION}

On the pathway of their inner democratic stabilization as well as reintegration into the modern world, the Balkan countries in transition lack a developed regional identity as $a$ transnational form of interest networking. ${ }^{1}$ As a new and authentic sphere of expression of the civil society, regional networking can help the Balkan countries achieve the status of an equal partner with the developed West. A good aspect of the Balkan regionalism would be also reflected in reaffirming the idea of civic activism as an already somewhat abandoned form of participation of a wide circle of citizens in dealing with the issues of relevance for their everyday life. Yet, what is the connection between regional networking and tolerance in ethnically, confessionally and religiously heterogeneous Balkan societies?

Tolerance is a fundamental assumption of civil society. Still, it does not imply, by any means, to be only tolerant to the other and the different (race, ethnos, religion, confession, etc.). It is wrong to regard tolerance as endurance since to endure means to have to undergo certain hardships. Self-restraint and care for others are at its very basis. Tolerance also expresses itself in our attitude to what is not close to us, in our readiness to reach, while setting up opposite arguments, a compromise as well as to respect what has already been agreed upon. Surely, there are boundaries of tolerance when nontolerance is expressed towards that which disturbs the realization of tolerance such as nationalism, fascism, racism, and the like.

A tolerant attitude towards "others" and the "different" also implies a dialogue with "those near us". At the very beginning of the new millennium the most important values tend to become plurality which respects the integrity of diverse traditions, and a dialogue approach towards other peoples, religions and confessions. The dialogue is a way towards harmony, a process assuming continuous interchange of the roles of "teacher" and "student", readiness to "give" as well as to "take". The dialogue is a sure sign of interpenetrating cultures, their mutual giving and taking - gift exchange - which is a far higher level than mere tolerance. Therefore, tolerance is a template for dialogue - without the foundation it lays no interpenetration of cultures would take place. Still, though natural, the dialogue is not an obligatory continuation of tolerance; also possible is tolerance without dialogue or a desire to get to know better others on the inside. Thus we come to the ground of theoretical debates about the essence of multiculturalism and interculturalism.

\section{ON THE ESSENCE OF MULTiCULTURALISM}

Multiculturalism has its „homeland“ and its roots, i.e., real multicultural societies in the European cultural space. The expression multiculturalism was first used by the Canadian Prime Minister Pierre Trideau in a speech made in 1971. Social sciences and philosophy took it into serious consideration not earlier than the eighties and particularly, in the last decade of the 20th century. The historical antecedent of multiculturalism was

\footnotetext{
${ }^{1}$ As early as mid-nineties of the twentieth century A. Molnar $(1994,150)$ predicted that "the path to Europe as a region leading through (postcommunist) Eastern Europe as a region probably will not be possible before even much narrower regions develop (such as Central European, Balkan, etc.)"
} 
cultural pluralism used for denoting a tolerant attitude among national cultures without paying regard to inter-cultural relations at the subnational level. Multiculturalism is defined as "an idea or ideal about harmonious co-existence of different ethnic and cultural groups within a pluralist society“ (Stojković 2004, 147), that is, ,it is based upon the idea of equal dignity of various culturally-defined groups and communities that set up co-existence in a democratic society as well as upon the belief stating that every human being has a right to grow within his own culture (without being subjected to the imposition of a cultural identity characteristic for the majority in the given society)" (Veljak 2017, 222).

At the very beginning multiculturalism was most often recognized as a component of the traditional political framework of public life in the USA. A specific combination of historical circumstances - presence of autochthonic peoples, shipment of slaves from West Africa, a variety of religious groups among the first settlers, Anglo-Saxon origin of economic and political elites as well as the role of immigration in settling the land - all this gave birth to the idea about the melting pot as a common denominator for comingling of diverse ethnic experiences on the American continent. However, first rather in muffled tones in the sixties and seventies and then more and more loudly in the last two decades of the last century, there appeared demands for preserving one's own identity on the part of the ethnic groups that used to be considered as „molten“ a long time ago. This opened up discussions about a monolithic nature of the American Dream and essential misunderstanding between the monocultural white majority averse to change and the multicultural ethnic minorities eager to change their own more or less unenviable positions. Multiculturalism outgrew the framework of America; it brought back to the European countries debates about ways of ordering pluralistic identity relationships.

In the public space two politics opposed each other, namely, the politics of "equal citizenship" and that of "difference”: „While the politics of dignity seeks to promote nondiscrimination among all citizens in a 'difference-blind' manner, the politics of difference often redefines nondiscrimination as requiring differential treatment based on individual and cultural distinctness" (Dallmayr 2002, 314). Inspired by multicultural demands in his country, especially those of the Quebec minority for advancement of the Francophonic cultural tradition, one of the leading Canadian philosophers, Charles Taylor in the text entitled The Politics of Recognition warns that no neutrality is possible in the situation when some groups are trying to preserve their cultural peculiarities while others try to promote individual interests. That is why he proposes a differentiated view of the concept of public life: "Indisputably, though, more and more societies today are turning out to be multicultural, in the sense of including more than one cultural community that wants to culturally survive. The rigidities of procedural liberalism may rapidly become impractical in tomorrow's world" (Taylor 2000, 36). ${ }^{2}$

According to Andrea Semprini, a French political analyst, multiculturalism is essentially raising three issues, i.e., those of diversity of society, of minority rights with respect to the majority, and of identity and its recognition. In the book with the same title, in accordance

\footnotetext{
${ }^{2}$ Unfortunately, Taylor remains within a vicious circle of the self-renewal of liberal society which would like, to remain liberal and, at the same time, to appreciate differences, that is, it tends to reconcile "equal recognition" of liberalism and "special recognition" of multiculturalism. More about the politics of recognition in: Taylor 2003.
} 
with a plethora of the existing answers to the issues in question, ${ }^{3}$ he is making a classification of multicultural approaches in the contemporary developed countries: 1 . A classical political liberal model (with a clear distinction of the public (voting right, freedom of speech and association, respect for law, taxpaying) from the private sphere (religious beliefs, gender, moral choice, customs, behavior) of human life in a society), 2. A multicultural liberal model (softening the line between the public and the private sphere, proclaiming the existence, within the social space, of a central ,monocultural“ zone and a multitude of peripheral zones in which all groups dispose of their own autonomy), 3. A maximalist multicultural model (rejecting the possibility of a single common sphere and giving priority to different kinds of collective identities (racial, ethnic, religious, etc.) as well as demands for their recognition), and, 4. A corporative multiculturalism model (diverse ethnic, racial, religious groups and social movements are only instrumented by big multinational companies for their own profit, not for affirming groups and realizing their welfare). ${ }^{4}$

In addition to the semblance of alternatives, the author points to the difficulty of perceiving a single authentic multicultural space in which different groups could satisfy their demands for recognition and identity as well as to preserve the presence of one collective dimension, as Semprini puts it, which "surmounts the horizons of ethnicity as well as civil and democratic institutions." The conditions for building up such a space would be: an increasingly important role played by individualistic instances (selfrealization, interior being, subjectivity), socio-cultural factors (values, life styles, private sphere) and demands for identity (need for recognition, affirmation of peculiarities) (Semprini 2004, 120-124).

The multicultural liberal model by the Canadian Will Kymlicka, one of the most important contemporary theorists of multiculturalism, has, for the time being, turned out to best withstand the test of reality. In his interpretation, this concept denotes institutional separation of cultural communities within one political community for the sake of preserving and protecting their special identity. In criticizing the classical liberal model and ethno-cultural neutrality of liberal states, most of all embodied in the USA behavior in managing ethno-cultural heterogeneity, he offers a liberal-democratic concept of ethnocultural justice which includes the presence of a separate space for minorities and a more uniform division of public space in society while it is based upon integration of minorities into a wide enough set up societal culture. ${ }^{5}$

Semprini himself, though, estimates that neither political institutions originating from Western culture nor their most prominent advocates are truly interested in promoting

\footnotetext{
${ }^{3}$ Some authors tend to stress there is no unique EU model of multiculturalism but the European countries rather set up their respective individual models according to the norms originating in their own pasts and traditions. Along this line of thought, Melita Richter-Malabotta (2005) distinguishes French "assimilation" model, German "Gastarbeiter" model, Italian model of segmented pluralism, in addition to the British, Dutch and North American model of "parallel worlds".

${ }^{4}$ A detailed survey of the above-mentioned classification in: Turza 2000.

5 "So a societal culture is a territorially-concentrated culture, centered on a shared language which is used in a wide range of societal institutions, in both public and private life (schools, media, law, economy, government, etc.). Participation in such societal cultures provides access to meaningful ways of life across the full range of human activities, including social, educational, religious, recreational, and economic life, encompassing both public and private spheres (...). It is possible for government policies to encourage the sustaining of two or more societal cultures within a single country."
} 
differences. Supportive of this estimate are the latest developments on the global scene. In the world public quite a stir was caused by the book Who Are We? The Challenges to America's National Identity by Samuel Huntington, a far and wide known author of The Clash of Civilizations and The Third Wave. In this book he proclaims the mission of rescuing „American soul“ by re-affirming unity and community, not diversity, as the prevailing American values. Like so many other critics, he proclaims multiculturalism an anti-West ideology and he openly attacks it since it, by promoting and strengthening of racial, ethnic, cultural and other subnational identities, primarily in the educational sphere, deconstructs American cultural and political identity. The desired American vision of multiculturalism is co-existence in the melting pot.

\section{DIFFERENCE BETWEEN MULTICULTURALISM AND INTERCULTURALISM}

Placed in the European context, the re-questioning of the EU enlargement policy towards the Western Balkan countries after the French and the Dutch rejected the European Constitution, that is, the conditioning of the countries whose perspective of EU membership was acknowledged (Romania, Bulgaria, Croatia) and those who are yet to become candidates by consistently performing state-legal reforms, testifies about anxieties of the club of Brussels. Though darkening of the European perspective and indirect announcements of postponement of new members admission are justified by functional and financial limitations restricting further enlargement of the European family as well as by "enlargement fatigue" or even by the need on the part of some present member states to apply the approval procedures that ensure new members are admitted only after gaining the consent of their citizens by referendum votes while offering to the states in the region special multilateral relations with the EU antecedent to full membership besides the forms of "privileged partnership", it is evident that the European idea about as wide unity in diversity as possible is withering away. ${ }^{6}$ In the situation when the whole of the Balkan region is evidently losing any near perspective for EU membership, between the lines, the question is raised whether it has become of crucial importance to strengthen the Balkan regional initiatives and go for their stronger interconnection through informal networks. ${ }^{7}$

We are of the opinion that behind all this there lies misunderstanding of the essence of multiculturalism, though some of our authors (Tripković 2004, 2005; Lošonc 2001; Divjak 2001), by gradation of its multi-layers, are trying to explore its perspective thoroughly.

Thus M. Tripković (2005, 90-91) elaborates: "Namely, while multiculturality denotes a real state... multiculturation would refer to the process based on the idea or ideal about a tolerant, equal, harmonious, interpenetrating (co)relation and common (co)existence of diverse cultures and subcultures within a more narrow or wider social space (local,

\footnotetext{
${ }^{6}$ The unified European market has additional fears of „,newcomers“ who would enjoy the blessings of their well-ordered and stable states as well as of increasing competition at the labor market which would threaten employment opportunities and lower wages due to unfair competition of their poor neighbors from European East and the Balkans.

${ }^{7}$ More exhaustive surveys of multicultural practices in Europe and in the Balkans in: Mesić 2006; StankovićPejnović 2010a, 2010b; Lošonc and Prole 2012; Миодраговић 2016; Bašić 2018; Bašić, Žagar and Tatalović 2018.
} 
regional, state, inter-state or world). In other words, though every society is more or less multicultural, not all of the societies tend towards multiculturation... ideal of multiculturation... in practice can easily be (ab)used and slip into the ideology of multiculturalism understood as a system of ideas in which are expressed, in a covert way, certain partial positions, interests and values of individuals and social groups which, surely, want to publicly pose as 'general' social interests." To this, he adds, "In principle, multiculturation is located between the extremes of cultural assimilation and cultural isolation and it is based, in fact, upon the principles of many-sided acculturation or interculturation." Tripković sums up, in the concept of multiculturation, the principles of interculturalism, as we understand and explain it, while his concept of multiculturalism that he criticizes, implies a classical political liberal model which is, at present, hidden under a cloak of dominant universal mass culture.

For Alpar Losoncz $(2001,23)$, multiculturalism is an expression of the inner dynamics of modernity while its "enlightening" role is implied in the fact that it sharpens the dilemmas of the democratic identity of liberal society in the light of cultural pluralism. Along with a special reference to the experience of the Central and Eastern European regions there goes the warning that a simple statement of the presence of distinctive identities is not sufficient, namely, "Only after it turns out that there is an interest in communication that is capable of changing us, and only if there is readiness to risk selfchange, can we speak about acceptance of other cultural identity... In the opposite case, we are only witnessing ideologizing of cultural pluralism and instrumenting of multiculturalism for actual-political purposes as well as unwilling acceptance of differences." The author well notices that the recognition of others is a necessary but not sufficient condition of their acceptance and thus he directs the creators of multicultural politics to expand their reach for which, in our opinion, multiculturalism is not capable of.

Slobodan Divjak (2001, 43-44) openly criticizes the ideology of radical cultural pluralism, that is, maximalist multiculturalism, due to "the understanding of singular cultures as closed, static, homogeneous and exclusive entities" along with an additional explanation that ,no approval could be given to the culture that regards the process of interaction of one culture with another and the practice of learning from other cultures as a threat to its 'integrity' instead as a chance for its own enrichment. The realization of these evident intercultural tendencies the author also sees in a harmonious coupling of moderate multiculturalism, civil-liberal state model and European constitutionalism: "From what has been said previously, it follows that Serbia must be constituted as a balanced combination of civil-liberal and multicultural models that will not call into question at least minimum of political and legal identity if it wants to stand out as a modern and relatively stable social system" $(2001,46)$.

As has already been emphasized, if we understand multiculturalism only as a coexistence of diverse cultures, then possible among them are tensions and conflicts, that is, between peoples as their carriers. Today's multicultural communities most often exhaust themselves in simple co-existence of differences with no intercultural communication or, as Z. Golubović describes it (1999), continuous cultural interaction through which there emerges a diffusion of cultural elements and styles among diverse collective and individual identities. Differences in multiculturalism have co-existed more than they have really interpenetrated. Therefore, concerning the possibilities of innovating the volume as well as the contents of multiculturalism, we do make missteps since it cannot further enlarge from what it is - a cultural model respecting differences and offering them a 
chance to enjoy in peace and develop its own cultural identity. It can be replaced only by interculturalism, ${ }^{8}$ or, as J. Cardoso $(1998,9)$ describes it, by supporting development of the communities in which minority groups would come into contact with the dominant cultures through an equal-footing interaction: "A multicultural society should possess the characteristics of a society in which different ethnic groups live together but with no interaction. The minority groups living therein are passively tolerated without being accepted by the majority group. An intercultural society should be defined as a society in which different groups live together and exchange their life experiences with mutual respect for their different styles of life and values." To this T. Inđić $(1995,245)$ adds, "The knowledge and understanding of other cultures as well as setting-up of positive relations of exchange and mutual enrichment among diverse cultural components within one community (state or community of many states, or the whole world) is the very essence of interculturalism."

That is why a correct starting definition of interculturalism would be that interculturalism is a critique and an alternative to multiculturalism. It is possible for the members of different cultures to live close to each other and that is the most crucial characteristic of multicultural societies. An intercultural society represents a society in which we live and create not close to each other but with each other and for each other. At the very core of intercultural requirements lies appreciation of differences. The experience of difference and encounter with others enable an individual to develop his own identity by comparing it with other identity models and guiding it to the realization that approaching others does not mean moving away from oneself. Interculturalism comprises uniqueness in differences, a balanced and high-quality presence of all ethnic factors in a society. Intercultural communication becomes a clearly constituted and a theoretically and empirically-founded area of scientific research (key research domains are: general conditions of intercultural communication, possibilities of contact among the cultural groups in touch, structure of intercultural communicative competence, non-verbal communication, etc.) (Rajić 1998; Čačić-Kumpes 1998; Dragojević 1999; Barett 2013). ${ }^{9}$

Branimir Stojković $(1997,194)$ joins the opinion of the theorists of interculturalism concerning the fact that the community of experience is what represents the basis for establishing successful communication between different groups: "The larger their common experience with respect to the overall experience of each participant in communication, the easier it is and closer to intracultural communication and vice versa - less common experience means a lesser possibility for successful and direct communication thus making the situation intercultural."

\footnotetext{
8 "Namely, the very prefixes in the given terms imply a difference: the first comprises an expression derived from Latin inter (between) suggesting dynamics and mutual relationships while the other one, derived from Latin multus (many) points to simultaneous existence of many different elements, in this case, cultures" (ČačićKumpes 1998, 75).

${ }^{9}$ The Council of Europe has adopted the White Paper on Intercultural Dialogue in which it has reached a conclusion that the best model of managing interethnic and intercultural relations must be based upon three assumptions: rejection of multiculturalism which endorses separation and is harmful to social cohesion, rejection of assimilation and violation of individual rights and, finally, promotion of interculturalism as a middle way of full and effective equality as well as the equal enjoyment or exercise of human rights.
} 
Viewed from the heights of theory, the intercultural society, in its ideal-type variant, truly is a positive-utopian project. ${ }^{10}$ Real-sociological objectivity does not lose sight of the fact that a road is long and troublesome between tolerant coexistence of diverse collectives and their cultures - even as parallel cultural universes - and their dynamic and meaningful inter-relations. Accordingly, it commands the human community not to be too easily pleased with tolerant "coexistence in difference" but to incessantly search for a multi-directional interaction of cultures of ever so many collectives making up a multiethnic society. Ryszard Kapuściński (2006, 29), a Polish author and journalist, quite nicely describes these strivings: "We say today that the world has become multiethnic and multicultural not because there are more of these communities and cultures than before, but rather because they are speaking out more loudly, with increasing selfsufficiency and forcefulness, demanding acceptance, recognition and a place at the round table of nations. (...) In this future world, we will constantly be encountering the new Other, who will slowly emerge from the chaos and tumult of our own present. We should seek dialogue and understanding with him. This new Other will arise from the meeting of two contradictory currents that shape the culture of the contemporary world - the current of the liberal globalization uniforming our reality and its opposite, the current of the conservation of our diversity, our differences, our uniqueness."

The question is now raised concerning cultural and civilization resources of the Balkan societies for accepting the "other" not as a hostile "other" but as a possible partner and associate. For Ljiljana Gavrilović $(2001,128)$, it is doubtless that communication between peoples from different Balkan cultural models is "a possibility of cooperation and association by which both the sides (if there are any at all) are winning and which is realized not by a conflict but by intercultural communication/dialogue". In this a decisive role in promoting cultural differences and education about the contents of the cultures in contact is played by a global communication network, i.e. Internet. Lino Veljak, a respected philosophical name from the former-Yugoslav science, stresses that at present there are, principally, two approaches to the research of culture and identity. The first has two dimensions or two faces, namely, a) traditionalist exclusivism (wished to be taken to and is actually being taken to the future) and b) false universalism (a circle marked as a false alternative); the turbo-folk culture represents a negative or destructive synthesis of these two dimensions. The other approach that the author wholeheartedly recommends to the Balkan countries is intercultural pluralism representing a productive synthesis of tradition and universality; as such it is in the function of development through valuing, preserving and exchanging elements of one's own cultural identity. ${ }^{11}$

The Balkan region has always been at the crossroads of the major world routes including those of ideas, customs, cultures, traditions and religions of the ancient Hellenic world and the Roman Empire, Byzantium, Ottoman Empire, Orthodox East and modern West, etc. Into the global planetary cultural model the Balkan cultural space

\footnotetext{
${ }^{10}$ Interculturalism especially seems an unattainable ideal in an active contact with the "policy of nondifferences" of liberalism which is based upon the principles of universal citizenry and individualist egalitarianism instead of the idea and promotion of collective rights and group identities and, as we are witnessing, it is obviously undergoing its revival in the West.

${ }^{11}$ A note taken during Prof. Lino Veljak's speech at the roundtable on The Needs and Possibilities for Creating the Center for the Balkan Cultural Studies at the University of Niš, held on Dec 3, 2005 at the Faculty of Philosophy, Niš.
} 
should be included exactly by putting forward its diversity and richness. In the process of adopting its social systems to the European setup and European democratic norms and values, the Balkan peoples have at their disposal only dialogue as a proper means of inter-communication. Accordingly, the contemporary Balkan society is facing the process of its transition from the multicultural into the intercultural one, that is, the process of spreading and adopting the idea and practice of interculturalism in a multicultural community. More precisely, this implies the development of the concept of a cultural and educational policy that would foster appreciation of cultural diversity and lead to the creation of a society in which different cultures interpenetrate. ${ }^{12}$

\section{INSTEAD OF A CONCLUSION: BALKANS AND INTERCULTURALISM}

T. H. Eriksen (2004, 211-214) reminds us that in their attitude towards minorities the states today turn to three major methods, namely, 1) assimilation or putting strong pressure upon minorities to give up their specific cultural distinctions which ultimately leads to their disappearance, 2) segregation or physical separation from majority which is most often justified by alleged cultural inferiority of minority, and 3) multiculturalism or adoption of such an the ideology that does not link citizenship and civil rights to the cultural identity of the majority but without insisting too much upon close linkage of that identity with those of minority cultural identities.

To the hegemonic politics of the state, the minorities can likewise respond in three ways: 1) by assimilation, 2) by acquiescing in their subordination or other ways of peaceful co-existence with the nation-state (they may sometimes negotiate for limited autonomy in religious, linguistic or local political matters) and 3) by exit or secession from the state framework. The given possibilities are of ideal-type character. In practice, both state tactics and minority responses will usually combine the first two strategies while a term commonly used to describe these combinations is integration. Integration implies the minorities' participation in the shared institutions of society while simultaneously they strengthen their group identity.

To the Western societies with the developed democratic institutions enabling a higher degree of emancipation, cooperation and integration of ethnic and religious groups and communities, the „Balkan worlds“ (Trajan Stojanović) have commonly served as a paradigm for marginalization of minority, ethnic and religious identity. The future of one's own ethnic and religious identity does not necessarily need to be built upon the opposite to what is even slightly different. The time is ripe for abandoning xenophobic fear of minorities; aggressive non-tolerance of the majority nations has brought with it only the retreat of national minorities into their (again national) shells. None of the nations can ever boast of its ways of regulating the status of national minorities if they keep on feeling jeopardized.

The support for an intercultural educational pattern - both by the highest state instances and at the local level - can crucially contribute to the acceptance of a common plural reality and the development of a form of communication that would affirm what is positive in this reality. Simultaneously, the idea of interculturalism would no longer

\footnotetext{
${ }^{12}$ It is understood that a positive cultural and educational policy should be accompanied with parallel steps taken in the sphere of employment and social care.
} 
represent isolated visionary strivings of some well-intentioned intellectuals but instead it would grow further and evolve into a completely new integrating social process.

In all this we should not lose sight of a far-reaching warning that "interculturalism cannot be intended only for others - minorities, migrants, etc." (Katunarić 1996, 850). "Deciphering interculturalism" does not imply any return to the discarded hierarchies and exclusiveness, that is, a unilateral incorporation of cultural achievements of the majority by the minority peoples. The dominant culture should, using primarily its own example, consistently support cultural heterogeneity ${ }^{13}$ by impartially strengthening and advancing minority cultures and enriching itself with the contents taken over from diverse cultural forms of life. Since intercultural harmony assumes a true interaction among cultural groups and it represents a true act of respect and appreciation of differences. Finally, why would not the Balkan countries "export" the described model of the intertwining domestic cultural traditions to the West, as a sort of an answer to what they are exposed to, namely, the ruthless and uncritical flooding with the Western democracy? ${ }^{14}$

Relying on the attempts made so far (Jovanov 2013; Brkić 2011) we propose the following measures of the public cultural policy of the Balkan countries to be taken for the sake of improving and advancing the existing intercultural dialogue:

- Formation of the state Commission for Intercultural Dialogue ${ }^{15}$

- Increased participation of the members of national minorities and vulnerable social groups in official state organs and bodies,

- Financing of diverse intercultural projects on the part of the republic ministries of culture, province and cantonal governments, city and local self-rules,

- Facilitated access to supranational networks and funds of the EU for supporting and financing intercultural projects,

- Promotion and mass attendance of transborder cooperation manifestations, ${ }^{16}$

- Advancement of tourist potentials in the border zones, ${ }^{17}$

- Strengthening of organizations of civil society for the sake of promoting intercultural dialogue (financial, tax and other exemptions),

\footnotetext{
${ }^{13}$ For intellectual honesty's sake, it should be said that "inhospitality to difference" is also implied in politically tinged demands of a certain minority ethnic group for participation in cultural life of the majority people along with simultaneous rejection to, under the pretense of preserving one's own identity, let cultural elements of the majority people actively take part in its cultural manifestations. And that is exactly characteristic of the behavior of the advocates of the Albanian national minority in Serbia and Macedonia.

${ }^{14}$ Even as far back as at the end of the last decade Jadranka Čačić-Kumpes $(1998,76)$ made a good point in her observation that "despite announced interactions and equal participation and exchange among all the cultures, the European intercultural experience has so far shown that its policy has most often come to inclusion of migrants and their marginalized cultures into the receiving society. Such an approach departs from the fundamental intercultural principles."

${ }^{15}$ In 2007 in Serbia the commission with the same title was formed within the Ministry of Culture of the Republic of Serbia

${ }^{16}$ At the mountain pass known as Kadu Boaz between Knyazhevats (Serbia) and Belogradchik (Bulgaria), once a year a border fair is organized. It begins with the official border opening ceremony and an interzone gets formed of several hundred meters for people from both the states to enter, have contacts and entertain themselves. More detailed in: Krstić 2011.

${ }^{17}$ Hunting Association of Central Serbia has been organizing, for more than two decades, Serbian-Romanian Hunters' Friendship Gatherings of hunters from Šumadija region and Caraș-Severin County. The Homeland society of the Timočani-Torlaci from Minićevo in Serbia and the Bulgarian Torlak association "Ždrepče" from Belogradchik organize once a year a common all-day socializing program: it is either the Torlak Evening in Minićevo in late March or the Torlak Meeting (Turlaška srešta) in Belogradchik in November or December.
} 
- Organizations of roundtables, public discussions and debates about intercultural dialogue,

- Common statements by mundane and religious institutions for condemning all sorts of expressions of racism and xenophobia,

- Production of documentary and similar programs that point to instances of "good intercultural practice" in different regions, ${ }^{18}$

- Multilingual editorial boards and departments within the media public service,

- Gastronomy Week - affirmation of the Balkan cuisines at local manifestations, ${ }^{19}$

- Encounters of Religions and Faiths - common programs of traditional churches and religious communities at the local level,

- Literary and Art Festivals - cooperation of Balkan writers and artists, ${ }^{20}$

- Theater Festivals - common performances of Balkan theaters, ${ }^{21}$

- Music Festivals - promotion of Balkan traditional music, ${ }^{22}$

- Choir Festivities - performances of Balkan music choirs, ${ }^{23}$

- Children's Festival - gatherings of Balkan and European children, ${ }^{24}$

- Sports Games - gatherings of athletes from Balkan countries, ${ }^{25}$

\footnotetext{
${ }^{18}$ About far and wide known Guča Trumpet Festival two documentary films are made so far, "Brasslands" by a team of Americans including Jay Arthur Sterrenberg and Adam Pogoff, and "Rock the Trumpet" by the Turkish director SaliSaliji - Sallini in addition to only one feature film entitled "Guča!" by the Serbian director Dušan Milić.

${ }^{19}$ Fair of Ethnic Food and Drinks in Belgrade is the largest and oldest traditional food product manufacturer show in Serbia, held since 2006

${ }^{20}$ Since 1991 in the vicinity of Niš an international literary colony Sićevo is organized as a public manifestation under the patronage of Niš Gallery of Contemporary Fine Arts. It gathers together the most important authors from Niš and Serbia as well as some notable foreign ones. In Vrbas, since 1969, a festival of youth poetry has been gathering young and unknown poets from former Yugoslavia. Today it is still one of the most important poetic manifestations intended for young poets from Serbia and the region.

${ }^{21}$ Yugoslav Drama Festival Without Translation has been held in Užice (Serbia), since 1996. In mid-February in Pleven (Bulgaria) an international theater association was founded, "7 Plus." It comprises theaters from Poland, Russia, Lithuania, Macedonia, Bulgaria and Serbia. Starting this year there is a theater festival in Niš, "Theater at the Crossroads," presenting performances from Serbia and the region (Slovenia, Bulgaria, Bosnia and Herzegovina, Montenegro); as a part of its program, a public discussion is planned under the title "Balkan Theater, Cooperation at the Crossroads." The idea is to offer a variety of platforms for dialogue among authors as well as possibilities of cooperation, starting with exchanges of performances and artists, through meetings of different generations to coproduction. Likewise, under the slogan "The whole city is a stage", there is a festival of international student theaters "Urban fest", held since 2011 in Niš. Its repertoire is mainly made up of performances produced by student and youth theaters from the region.

${ }^{22}$ The Guča Trumpet Festival, also known as the Dragačevski Sabor, is an annual brass band festival as well as a festival of folklore and folk art, held in the town of Guča, in the Dragačevo region of western Serbia, held since 1961. Yet it became a worldwide known competition of the trumpet masters, famous for its co-mingling of Serbian and Roma "trumpet dialects" only in the last decade.

${ }^{23}$ Since 1966, every other year, a festival of amateur choral singing is held in Niš first under the title Yugoslav Choral Festival and today as International Choir Festival. Its program includes performances of amateur choirs from the entire world, as well as accompanying events such as thematic public discussions, choir studios, exhibitions etc. In Negotin, also starting in 1966, choir festivities named "Days of Mokranjac" take place as a tribute to the most prominent Serbian composer Stevan Mokranjac with many choirs from the region as honored participants.

${ }^{24}$ Children's manifestation Joy of Europe as the largest and oldest international manifestation of children's creativity was established a long time ago, in 1969. In addition to music performances, groups of European children exhibit their dances, culture and customs of their countries while socializing for a whole week in the Serbian capital.

${ }^{25}$ Intermunicipal youth sports games of the municipalities from the three-state border area (of Bosnia and Herzegovina, Montenegro and Serbia), the largest exhibition of amateur sports in the Balkans and Southeastern Europe is held since 1964.
} 
- Performances of young artists from different national communities and further orientation to cooperation and common projects, ${ }^{26}$

- Encouragement of cultural amateurism of national communities, ${ }^{27}$

- Support for establishing and advancing activities of Cultural Centers of national minorities, ${ }^{28}$

- Seminars as a means of informing wider population about holidays and customs of minority nations and their common celebrations, ${ }^{29}$

- Literary seminars about works of the authors from minority national groups, ${ }^{30}$

- Organization of multicultural voluntary camps for children and youth, ${ }^{31}$

- Creation of educational programs for primary and secondary schools about intercultural dialogue, ${ }^{32}$

- Introduction of Romology as an academic discipline that would provide knowledge about Romas as a transnational ethnic and cultural minority in the Balkans,

- Publishing of professional and scientific journals with intercultural contents, ${ }^{33}$

- National minorities' language learning courses, and,

- Intense cooperation of the National Minorities Councils in national and international frameworks.

${ }^{26}$ Guitar Art Summer Fest in Herceg Novi in Montenegro has been gathering, since 2006, leading world virtuosi guitarists as well as guitar-lovers among elementary and secondary school kids and students from the whole Balkan region. Likewise, since 2004, an international competition of guitarists named Naissus Guitar Festival is held in Niš, also including prominent guitar players.

${ }^{27}$ Student Cultural Center of the University of Niš, since 2008, organizes International Student Festival of Folklore. Also, in Vršac, since 1993, an international festival of folklore is organized under the name Vršački venac. The Movement for the Development of Eastern Serbia, since 2011, organizes an international folklore festival, Malinik.

${ }^{28}$ With the support from the City of Niš, the preparations are made for opening up Roma Cultural Center in the local community "February $12 . "$

29 "Dužijanca" is a harvest festivity celebrated in Subotica for more than a century. As a cultural project, since 1993, it comprises a series of different manifestations with the aim to promote Bunjevac Croats. It is a good example of preserving the tradition of the masqueraded carnival parade "Mačkare," organized as a custom of the Croats of Golubinci, Srem, as well as masked "Tute" as a custom of Škci in Bačka.

${ }^{30}$ In Croatia a literary seminar entitled the "Days of Vladan Desnica" is named after a famous Croatian writer of Serbian nationality.

${ }^{31}$ Evangelical Academy of Transylvania organizes, once a year, a summer camp "Come, See, Pack." Young German-speaking people from Serbia and Romania, 16- to 20- year-olds, stay for a week in the city of Sibiu in Romania. They play and socialize while, at the same time, they get to know the culture of the neighboring people.

${ }^{32}$ As a part of the research project "Transborder Intercultural Cooperation of Educational Institutions of the Republic of Serbia and the Republic of Croatia" conducted by the Ministry of Education, Science and Technological Development of the Republic of Serbia and the Ministry of Science and Education of the Republic of Croatia together with the Nansen Dialogue Center Serbia and Nansen Dialogue Center Osijek, in Gymnasium "Svetozar Marković" in Subotica a teachers' training course took place on Oct 12-14, 2018, including the teachers from Elementary School "Julije Benešićc" (Ilok), Elementary School „Matija Gubec“ (Tavankut), Gymnasium „Svetozar Marković“ (Subotica) and First Secondary School (Beli Manastir). Group 484 and the Service of the Coordinate Body of the Government of the Republic of Serbia for the Municipalities of Preševo, Bujanovac and Medveđa organized, from April to December, 2017, at the Economic Faculty of Bujanovac, a professional specialization seminar entitled „Us and Them“ accredited for competences in intercultural and interethnic cooperation and especially customized to the specific characteristics of these communities. It was designed for 70 teachers of social and humanist sciences and languages from 2 secondary and 4 elementary schools.

33 The Cultural Institute of Vojvodina publishes a journal for stimulation and affirmation of intercultural communication, Interculturality. The Faculty of Philosophy of the University of Niš is the publisher of the Balkan Syntheses, a journal issuing articles in the languages of the Balkan peoples. 
Acknowledgement: Prepared as a part of the project Sustainability of the Identity of Serbs and National Minorities in the Border Municipalities of East and Southeast Serbia (179013), carried out at the University of Niš - Faculty of Mechanical Engineering, and supported by the Ministry of Education, Science and Technological Development of the Republic of Serbia.

\section{REFERENCES}

Barrett, M., ed. Interculturalism and Multiculturalism: Similarities and Differences. Strasbourg: Council of Europe Publishing, 2013.

Bašić, G. Multikulturalizam i etnicitet. Beograd: Institut društvenih nauka, 2018.

Bašić, G., M. Žagar, and S. Tatalović. Multiculturalism in Public Policies. Belgrade, Ljubljana and Zagreb: Institute of Social Sciences, Academic Network for Cooperation in South East Europe, Institute for Ethnic Studies and Centar for International and Security Studies of Faculty of Political Sciences, 2018.

Brkić, A. „Interkulturni dijalog kroz aktere, strategije i programe studije slučaja: Ujedinjeno kraljevstvo Velike Britanije i Severne Irske, Italija, Makedonija i Srbija“. Zbornik radova Fakulteta dramskih umetnosti 18 (2011): 49-66.

Čačić-Kumpes, J. "Etničke raznolikosti u Europi i politika kulturnog pluralizma". U Etničnost, nacija identitet, priredili R. Čičak-Chand i J. Kumpes, 71-83. Zagreb: Institut za migracije i narodnost, Naklada Jesenski i Turk i Hrvatsko sociološko društvo, 1998.

Dimitrijević, B., ur. Bela knjiga o interkulturnom dijalogu „Živimo zajedno jednaki u dostojanstvu“. Beograd: Ministarstvo kulture Republike Srbije, 2009.

Дивјак, С. "Мултикултурализам - комунитаризам - либерализам“. Нова српска политичка мисао VIII, 1-4 (2001): 25-47.

Dolmear, F. "Demokratija i multikulturalizam”. U Nacija, kultura i građanstvo, priredio S. Divjak, 303-321. Beograd: Službeni list SRJ, 2002.

Dragojević, S. "Multikulturalizam, interkulturalizam, transkulturalizam, plurikulturalizam: suprotstavljeni ili nadopunjujući koncepti”. U Kultura, etničnost, identitet, priredio J. Čačić-Kumpes, 77-90. Zagreb: Institut za migracije i narodnost, Naklada Jesenski i Turk i Hrvatsko sociološko društvo, 1999.

Eriksen, T. H. Etnicitet i nacionalizam. Beograd: Biblioteka XX vek, 2004.

Гавриловић, љ. "Меклуан и сан о Златном Добу Шљиве“. Нова српска политичка мисао VIII, 1-4 (2001): 111-135.

Golubović, Z. Ja i drugi (Antropološka istraživanja individualnog i kolektivnog identiteta). Beograd: Republika, 1999. Dostupno na: http://www.yurope.com/zines/republika/arhiva/99/jaidrugi.html

Inđić, T. "Interkulturalizam, nacija i religija”. U Interkulturalnost u multietničkim društvima, uredio B. Jakšić, 245-263. Beograd: Forum za etničke odnose, 1995.

Jovanov, L. „Različite perspektive tumačenja interkulturalizma - Francuska, Nemačka, Hrvatska i Srbija“. Antropologija 13, 3 (2013): 109-130.

Капучински, Р. „Срести странца, одлучујући догађај“. Le Monde diplomatique (издање на српском језику) 2, 3 (2006): 28-29.

Cardos, I. "Multikulturno obrazovanje prema interkulturnom obrazovanju". U Obrazovanje Roma - stanje $i$ perspective, 9-10. Beograd: Društvo za unapređivanje romskih naselja i Komisija za proučavanje života i običaja Roma SANU, 1998.

Katunarić, V. "Tri lica kulture”. Društvena istraživanja 5, 5-6 (1996): 831-858.

Kymlicka, W. "Etnički odnosi i zapadna politička teorija”. Habitus, nulti broj, (1999): 17-68.

Крстић, Д. “Сабор на Кадибогазу: прилог познавању граничних сабора“. Теме 35, 4 (2011), 1575-1602.

Лошонц, А. "Културна плуралност: апотеоза различитости или пракса прихватања“. Нова српска политичка мисао VIII, 1-4 (2001): 7-23.

Lošonc, A. i D. Prole, prir. Aporije multikulturalizma. Novi Sad: Mediterran Publishing, 2012.

Миодраговић, Б. Мултикултурализам: успон и пад једне идеје. Бања Лука: Универзитет у Бањој Луци Факултет политичких наука, 2016.

Molnar, A. "Socijalna, socijalno-politička i politička demokratija - mogućnosti razgraničenja, perspektive međuzavisnosti i potrebe usklađivanja”. U Regionalizam kao put ka otvorenom društvu, 107-155. Novi Sad: VISIO MUNDI Academic Press, 1994.

Rajić, Lj. „Interkulturalno opštenje između računa i uživljavanja”. U Rasizam i ksenofobija, uredio B. Jakšić, 57-70. Beograd: Forum za etničke odnose, 1998. 
Richter-Malabotta, M. „Managing Cultural Transitions: Multiculturalism, Interculturalism and Minority Policies". In The Emerging Creative Industries in Southeastern Europe, edited by N. Švob-Đokić, 113125. Zagreb: Institute for International Relations, 2005.

Semprini, A. Multikulturalizam. Beograd: CLIO, 1999.

Stanković-Pejnović, V. "Identitet i multikulturalizam nacionalnih država na Balkanu". Matica 11, 43 (2010a), $127-156$.

Stanković-Pejnović, V. “Mogu li 'nacionalne države' na Balkanu negirati multikulturalizam?”. Sociološka luča 4, 2 (2010b): 103-115.

Stojković, B. "Granice, manjine i stranci u interkulturnom prostoru Balkana". U Granice - izazov interkulturalnosti, uredio B. Jakšić, 189-200. Beograd: Forum za etničke odnose, 1997.

Stojković, B. "Multikulturalizam, Balkan i planetarna kultura". U Multikulturalizam (147-59). Beograd: Clio, 2004.

Tejlor, С. "Politika priznavanja". Habitus 1 (2000): 1-44.

Tejlor, Č. i sar. Multikulturalizam - ispitivanje politike priznanja. Novi Sad: Centar za multikulturalnost, 2003.

Трипковић, М. "Мултикултуралност и регионализација у условима транзиције“. Социолошки преглед 38 , 1-2 (2004): 189-203.

Трипковић, М. “Мултикултуралност, мултикултурација и права мањина“. Социолошки преглед 39, 1 (2005): 81-95.

Turza, K. "O multikulturalizmu”. Republika 12, 251 (2000).

Veljak, L. "Multikulturalizam nasuprot fundamentalizma”. Filozofska istraživanja 37, 2 (2017): 221-229.

\section{TOLERANCIJA, MULTIKULTURALIZAM I INTERKULTURALIZAM NA BALKANU}

Multikulturno društvo bi trebalo imati karakteristike društva u kome različite etničke grupe žive zajedno, ali bez interakcije. U njemu se manjinske grupe pasivno tolerišu, ali nisu prihvaćene od većinske grupe. Interkulturalno društvo bi trebalo definisati kao društvo gde različite grupe žive zajedno, razmenjuju životna iskustva, poštujući međusobno različite stilove života i vrednosti. Zato bi korektna polazna definicija interkulturalizma bila da je interkulturalizam kritika $i$ alternativa multikulturalizma. Moguće je da pripadnici različitih kultura žive jedni pored drugih, i to je najbitnija odlika multikulturnih društava. Interkulturno društvo označava društvo u kome živimo $i$ stvaramo ne jedni pored drugih, već jedni sa drugima i jedni za druge.

Shodno izrečenom, savremenom balkanskom društvu predstoji prerastanje iz multikulturnog $u$ interkulturno, odnosno širenje i usvajanje ideje i prakse interkulturalizma u višekulturnoj zajednici. Preciznije rečeno, razvijanje koncepta kulturne i obrazovne politike koji će unapređivati poštovanje kulturnog diverziteta $i$ voditi stvaranju društva u kojem se različite kulture prožimaju.

Na kraju rada sumiraju se mere javne kulturne politike balkanskih zemalja za poboljšanje $i$ unapređenje postojećeg interkulturnog dijaloga.

Ključne reči: protestantizam, Balkan, dijalog, tolerancija, multikulturalizam, interkulturalizam, mere javne kulturne politike. 